\title{
A NEW SPECIES OF PEPEROMIA (PIPERACEAE) FROM EQUADOR
}

\author{
C. C. BERG, E. A. MENNEGA and J. TOLSMA
}

Instituut voor Systematische Plantkunde, Rijksuniversiteit Utrecht

\section{SUMMARY}

A new species of Peperomia, $P$. rugosa from Napo (Ecuador) is described and its position in the genus briefly discussed.

\section{INTRODUCTION}

At the end of 1976 the Instituut voor Systematische Plantkunde received a request from a commercial grower. $\mathrm{Mr}$. van der Velden. to identify a species of Peperomia which he wanted to introduce into the trade. Mr. van der Velden received this plant from $\mathrm{Mr}$. H. Prinsler who collected the material in Ecuador. As the specimen did not match any of the descriptions of the known species of Peperomia more plants were grown from cuttings at the Utrecht Botanical Garden. From the ample material the authors decided that the specimen belongs to a hitherto unknown species of Peperomia.

\section{DESCRIPTION}

Peperomia rugosa C. C. Berg, E. A. Mennega \& J. Tolsma nov. spec. Herba suberecta usque $30 \mathrm{~cm}$ alta. Caulis dense minuteque puberulus, rufus. Folia alterna. Lamina saepe ovata, 3-9 $\mathrm{cm}$ longa, basi plerumque rotundata vel cordata. apice plerumque subacuta. supra rugosa, atroviridis. striis grisaceis venis interpositis $6 \mathrm{vel} 8$, venis primariis palmatis 9-11, nervatura infra rubra. petiolus 1-3 (-4) cm longus. Inflorescentiae singulae, foliis oppositis, vel binae ternaeve inaequalis, in panicula terminali dispositae, pedunculus ad $2.5 \mathrm{~cm}$ longus. rufus: spica ad $9 \mathrm{~cm}$ longa: ovarium mammiforme, stigmate apicali.

Herbs up to $30 \mathrm{~cm}$ high, suberect. Stem brownish red, succulent, densely and minutely puberulous, at the base up to $10 \mathrm{~mm}$ in diameter. internodes up to $2 \mathrm{~cm}$ long. ribbed.

Leaves alternate. Lamina mostly ovate, sometimes almost orbicular or el- 


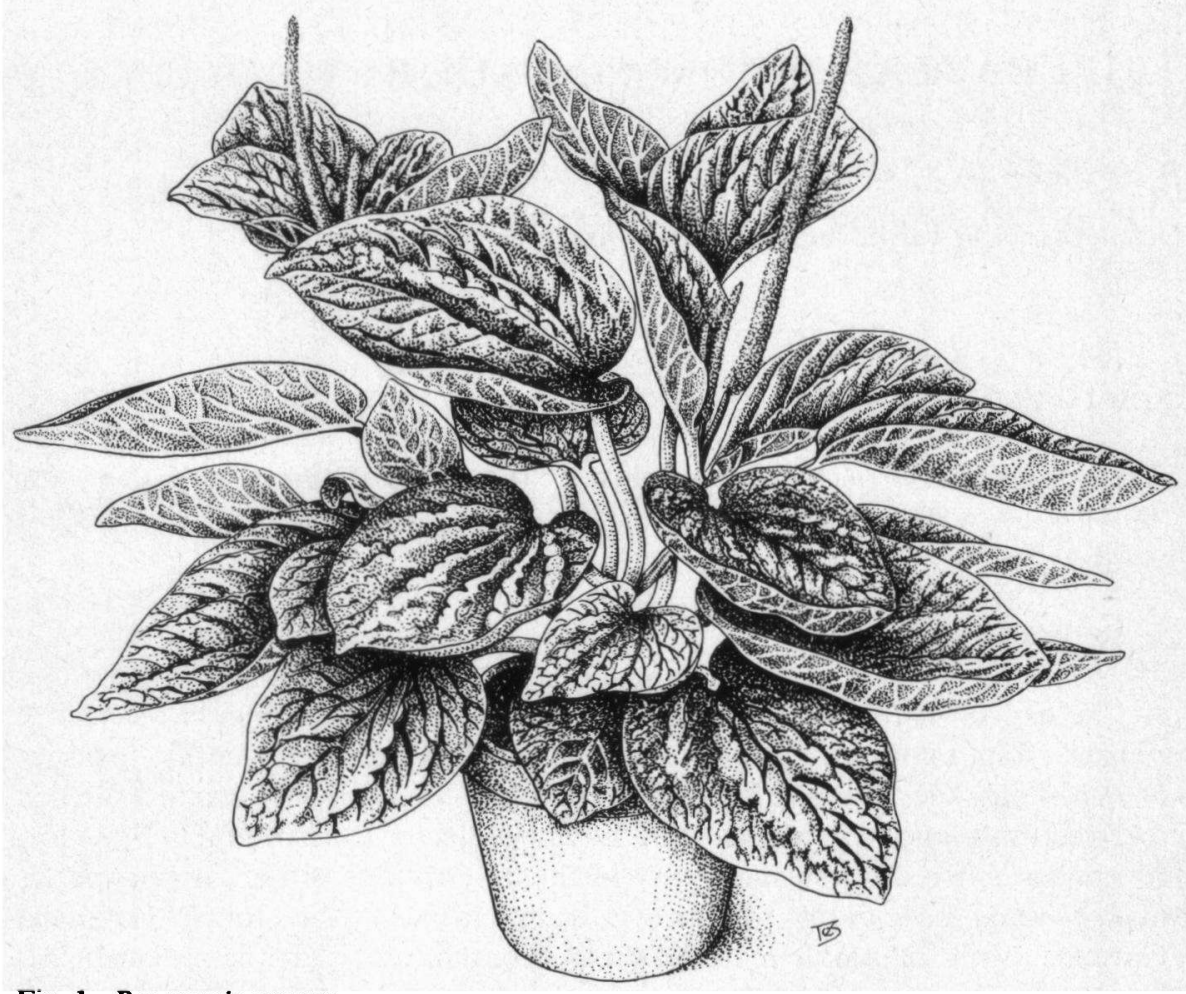

Fig. 1. Peperomia rugosa.

liptic, 3-9 $\mathrm{cm}$ long, $2-8.5 \mathrm{~cm}$ broad. more or less plicate: apex subacute to almost rounded or shortly acuminate: base mostly rounded or more or less cordate, sometimes truncate or acute: margin subentire. involute: upper surface rugose. dark-green and mostly with 6 or 8 greyish streaks between the nerves. with sparse minute hairs: lower surface entirely of partly reddish or only the venation red: with prominent nerves and veins. densely and minutely puberulous on the nerves and veins only: palmately 9-(11-) nerved. veins almost lacking in the lower part of the lamina: petioles reddish. $1-3(-4) \mathrm{cm}$ long. densely and minutely puberulous. Scale leaves at the base of branches and inflorescenses up to $8 \mathrm{~mm}$ long.

Spikes solitary and leaf-opposed, or 2-3 unequal spikes in a terminal panicle. the secondary spikes subtended by a scale leaf: peduncle reddish, up to $2.5 \mathrm{~cm}$ long. densely and minutely puberulous: spike up to $9 \mathrm{~cm}$ long and up to $5 \mathrm{~mm}$ in diameter: flowers closely set, sometimes remote (sterile) flowers down to halfway the peduncle: ovary mammiform and muriculate, stigma apical: interfloral bracts round-peltate: fruit unknown.

TYPE: Ecuador (Napo) near Puyo, collected by H. Prinsler (1973) and cultivated by J. M. C. van der Velden \& Sons, Sint Oedenrode (Netherlands), in Herba- 
rium Utrecht sub Horto Botanico 77-100 (Holotype: U: isotypes: K: NY: F: S: US: Z).

\section{COMMENT}

Peperomia rugosa belongs to the subgenus Tildenia (Miq.) Dahlstedt (cf. T. G. YUNCKER 1974). The species more or less resembles $P$. rubramente Yuncker (with much longer petioles), $P$. perlongipedunculata Trelease \& Yuncker (upper surface of leaves glabrous), $P$. elsana Trelease \& Yuncker (stem glabrescent below) and $P$. valladolidana Yuncker (leaves silvery beneath) (cf. TRELEASE \& YUNCKER 1950) and $P$. rubrifolia Trelease (plant glabrous) (cf. TRELEASE 1936).

\section{ACKNOWLEDGEMENTS}

We thank Prof. Dr. K. U. Kramer for contributing the Latin diagnosis, Mr. T. Schipper who made the drawing and Mr. J. M. C. van der Velden for generously supplying some living plants for investigation.

\section{REFERENCES}

Trelease, W. (1936): Flora of Peru - Piperaceae. Field Mus. Nat. Hist., Bot. Ser. 13, no. 357. - \& T. G. YUNCKER (1950): The Piperaceae of Northern South America.

YUNCKER, T. G. (1974): The Piperaceae of Brazil III. Hoehnea 4: 71-413. 